\title{
The Effect of Internal Marketing on Competitive Advantage as Organizational Coaching - Mediating Effect of Service Innovation
}

\author{
Mi-sook Yeum ${ }^{1}$, Kuk-hoan Wee ${ }^{2}$ and Won-seok Bang ${ }^{3}$ \\ ${ }^{1}$ Korea Human Resources Bank, Korea \\ ${ }^{2}$ Sungduk University, Korea \\ ${ }^{3}$ Gyeongnam National University, Korea \\ ${ }^{1} Y m s u k 1966 @ n a v e r . c o m,{ }^{2}$ Wkh64@sdc.ac.kr, ${ }^{3}$ Bangws@daum.net
}

\begin{abstract}
The purpose of this study is to examine the effect of internal marketing (IM) on competitive advantage in the organizational coaching approach to gain competitive advantage in Korea. This study is to construct the sub - elements of IM as communication, compensation, and empowerment, and to identify the relationships among IM, service innovation and competitive advantage. To accomplish the purpose of this study, we conducted a questionnaire survey of 220 employees working in three branches of the Korea Health Care Association, and collected the data and verified the hypotheses through SPSS and AMOS analysis. As a result, IM has a significant effect on service innovation positive and direct influence on competitive advantage respectively as organizational coaching. However, the relationship between IM and service innovation did not supported. In other words, there is no mediating effect of service innovation on the relationship between IM and competitive advantage. These results suggest that IM enhances competitive advantage as a role of organizational coaching. Therefore, this paper suggests practical implications for public hospital managers, including private hospital managers, from a management perspective.
\end{abstract}

Keywords: Internal Marketing, Service Innovation, Competitive Advantage, Organizational Coaching

\section{Introduction}

With a rapidly changing competition environment, organizations including hospitals has a problem of how to enhance the competitive advantage. One of the solutions of this problem is the internal marketing(IM) that has an effect of the employee attitude and changes the process of service with new idea, in turn lead to competitive advantage. According to survey results in the past few years, even though customers have paid more attention to healthy ratios [1] and pay attention to keeping good health, increase in hospitals supporting many diverse and convenient service is drawing fierce in competition. In these keen competition, all organization including even non-profit organization has attempted to gain the competitive advantage. One of the solutions about this problem, internal elements of organization must be focused. Subdimensions of IM as an organization coaching such as communication, reward are very essential element to competitive advantage.

Article history:

Received (March 21, 2019), Review Result (June 26, 2019), Accepted (July 25, 2019) 
Meanwhile, innovation and new ideas come from factors within and outside an organization [2][3]. This paper focused on the internal view of organization as an organization coaching.

Therefore, we suggested that IM is the important variable that gains the sustainable competitive advantage. This research focused on the aspects of IM as an organizational coaching and innovation that lead to competitive advantages in the hospital industry.

\section{Literature review}

Recently, Papadas et al. proposed that internal green marketing has an effect on relationship between strategic and competitive advantage as a moderator in the study on the interplay of strategic and internal green marketing orientation on competitive advantage [4]. Meanwhile, Ieong and Lam offered five dimensions of IM, following elements: vision, communication, overall development, job training and reward system [5]. Based on the previous review, we employed three elements of IM: communication, empowerment, reward.

Tsai and $\mathrm{Wu}$ found that there is a positive relationship between IM and service innovation for nurses in hospitals, and recommended that nursing managers of hospitals strengthen service innovation by employing IM. They proposed that education and training are often used to positively influence the innovative ability of employees in order to increase a hospital's internal resource capacity [6]. Thus, nursing managers of hospitals could apply education and training strategies derived from IM practices to increase nurses' knowledge, improve their nursing care and innovation skills and improve the quality of service to patients. On the other hand, a study on creating competitive advantage through IM in the medical industry, Bang proposed that IM is the antecedent of self-efficacy, internal customer satisfaction and service innovation. That's IM has a positive effect on service innovation. So, top and middle managers must understand that IM activities such as open and effective internal communication to understand employees'needs, training and education have been mixed well to develop internal customers' ability as well as to motivate internal customers toward service mindedness and improvement of service quality, appropriate reward system to motivate the members of the organization such as developing the competence-based reward [7].

This paper aims to identify the IM according to the three sub-dimensions and the relationship between IM and service innovation and competitive advantage, achieving several theoretical and managerial contributions.

\section{Methodology}

\subsection{Conceptual model}

This paper is to investigate the relationships among IM, service innovation and competitive advantage for the hospital organization.

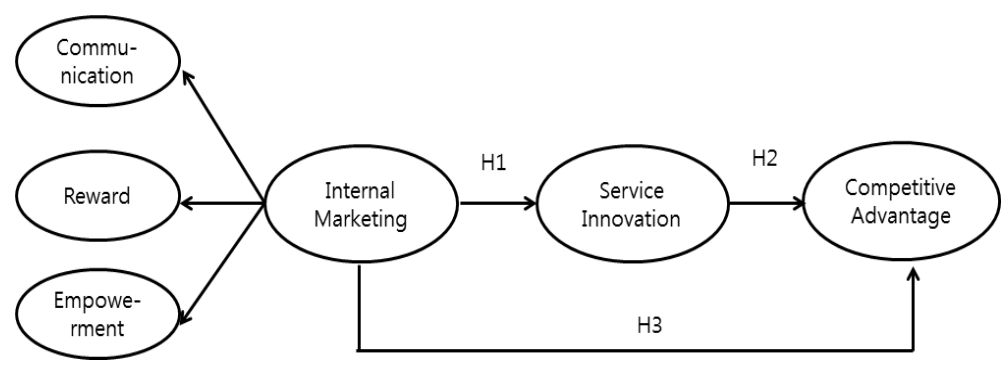

Figure 1. Conceptual model 


\subsection{Samples}

A survey for some schools in Gyeongnam province in Korea was conducted to collect data. When sending out the 220 questionnaires, we apply cross test and random order items to avoid common method biases. Altogether, we get 214 respondents. We delete 15 invalid replies and get 199 valid respondents at the end.

\section{Results}

\subsection{Result of confirmatory analysis}

The CFA results are presented in Table 1. The reliability (Cronbach's a) of each construct is more than 0.6, composite reliability of all indicators were above thresholds, which exceeds the acceptable level suggested by Murphy and Davidshofer (1988) [8] and by Nunnally and Bernstin (1994) [9]. So, all factor loadings were statistically significant and reliabilities were above 0.7 . The average variation extracted (AVE) values for all constructs were above 0.5 . The results of CFA supported discriminant validity due to all indicators fitted. The CFA model indicated good fit to data.

Table 1. Results of confirmatory factor analyses

\begin{tabular}{|c|c|c|c|c|c|c|c|}
\hline Variables & Items & Estimates & SE & $\mathrm{T}$ value & Cronbach' $\alpha$ & $\mathrm{CR}$ & AVE \\
\hline \multirow{4}{*}{ communication } & $\mathrm{X} 1$ & 0.873 & - & - & \multirow{4}{*}{0.910} & \multirow{4}{*}{0.911} & \multirow{4}{*}{0.719} \\
\hline & $\mathrm{X} 2$ & 0.841 & 0.057 & 15.834 & & & \\
\hline & X3 & 0.804 & 0.063 & 14.608 & & & \\
\hline & $\mathrm{X} 4$ & 0.873 & 0.062 & 16.930 & & & \\
\hline \multirow{5}{*}{ reward } & X6 & 0.843 & 0.066 & 15.403 & \multirow{5}{*}{0.926} & \multirow{5}{*}{0.857} & \multirow{5}{*}{0.735} \\
\hline & $\mathrm{X} 7$ & 0.876 & 0.063 & 16.500 & & & \\
\hline & $\mathrm{X} 8$ & 0.812 & 0.062 & 14.464 & & & \\
\hline & $\mathrm{X} 9$ & 0.854 & 0.063 & 15.746 & & & \\
\hline & $\mathrm{X} 10$ & 0.849 & - & - & & & \\
\hline \multirow{4}{*}{ empowerment } & $\mathrm{X} 11$ & 0.865 & - & - & \multirow{4}{*}{0.926} & \multirow{4}{*}{0.919} & \multirow{4}{*}{0.739} \\
\hline & $\mathrm{X} 12$ & 0.839 & 0.054 & 17.547 & & & \\
\hline & $\mathrm{X} 13$ & 0.891 & 0.057 & 16.496 & & & \\
\hline & $\mathrm{X} 14$ & 0.843 & 0.054 & 18.703 & & & \\
\hline \multirow{3}{*}{$\begin{array}{c}\text { service } \\
\text { innovation }\end{array}$} & $\mathrm{X} 15$ & 0.835 & - & - & \multirow{3}{*}{0.888} & \multirow{3}{*}{0.889} & \multirow{3}{*}{0.727} \\
\hline & $\mathrm{X} 16$ & 0.879 & 0.067 & 14.331 & & & \\
\hline & $\mathrm{X} 17$ & 0.844 & 0.065 & 15.371 & & & \\
\hline \multirow{3}{*}{$\begin{array}{l}\text { competitive } \\
\text { advantage }\end{array}$} & X19 & 0.877 & - & - & \multirow{3}{*}{0.902} & \multirow{3}{*}{0.907} & \multirow{3}{*}{0.766} \\
\hline & $\mathrm{X} 20$ & 0.932 & 0.058 & 18.802 & & & \\
\hline & $\mathrm{X} 21$ & 0.812 & 0.066 & 14.967 & & & \\
\hline \multicolumn{8}{|c|}{$\begin{array}{c}\chi^{2} / \mathrm{df}=275.528(142), \mathrm{p}=0.000, \mathrm{CMIN} / \mathrm{DF}=1.940, \mathrm{GFI}=0.881, \mathrm{IFI}=0.962, \mathrm{TLI}=0.954, \mathrm{CFI}=0.962, \\
\text { RMSEA }=0.075\end{array}$} \\
\hline
\end{tabular}




\subsection{Result of correlations analysis}

[Table 2] reported the results of correlations identified. The analysis verified discriminant validity, the square root of AVE of each factor was larger than the correlation coefficients between the factors (off-diagonal elements) [10]. So the discriminant validity of all measurements used can be verified.

Table 2. Results of correlation analysis

\begin{tabular}{|c|c|c|c|c|c|}
\hline & $\mathrm{CO}$ & RS & EM & SI & $\mathrm{CA}$ \\
\hline Communication & 0.848 & & & & \\
\hline Reward system & $0.150^{*}$ & 0.857 & & & \\
\hline Empowerment & $0.165^{*}$ & $0.388 * *$ & 0.860 & & \\
\hline Service innovation & 0.023 & 0.133 & $0.256^{* *}$ & 0.853 & \\
\hline $\begin{array}{l}\text { Competitive } \\
\text { advantage }\end{array}$ & 0.072 & $0.164 *$ & $0.200 * *$ & $0.199 * *$ & 0.875 \\
\hline \multicolumn{6}{|c|}{$\begin{array}{c}\text { CO: communication of IM, RS: Reward system of IM,, EM; Empowerment, SI: Service } \\
\text { innovation, CA: Competitive advantage }\end{array}$} \\
\hline
\end{tabular}

\subsection{Results of path analysis}

As shown in Table 3, all hypotheses in the path analysis are supported except for the relationship between service innovation and competitive advantage. That's, IM is positively related to service innovation $(\beta=0.676, p=0.001)$ and competitive advantage $(\beta=-0.653$, $p=0.001)$, supporting $H 1$, and $H 3$, respectively. However, $H 2$ is not supported $(\beta=-0.100$, $\mathrm{p}=0.05)$.

Table 3. Results of path analyses

\begin{tabular}{|c|c|c|c|c|c|c|}
\hline Hypothesis & Path & Estimates & SE & T-value & $\mathrm{p}$-value & Results \\
\hline $\mathrm{H} 1$ & $\begin{array}{l}\text { Internal marketing } \\
\rightarrow \text { Service innovation }\end{array}$ & 0.676 & 0.069 & $9.769 * * *$ & 0.000 & Supported \\
\hline $\mathrm{H} 2$ & $\begin{array}{c}\text { Service innovation } \\
\rightarrow \text { Competitive } \\
\text { advantage }\end{array}$ & 0.100 & 0.125 & 0.799 & 0.424 & Unsupported \\
\hline $\mathrm{H} 3$ & $\begin{array}{l}\text { Internal marketing } \\
\rightarrow \text { Competitive } \\
\text { advantage }\end{array}$ & 0.653 & 0.111 & $5.869 * *$ & 0.000 & Supported \\
\hline \multicolumn{7}{|c|}{ 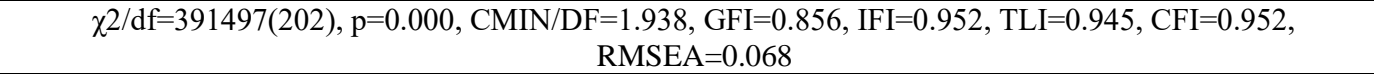 } \\
\hline
\end{tabular}

\section{Conclusions}

This paper examined to identify the IM according to the three dimensions and the relationship between IM and service innovation and hospital competitive advantage. The results showed that IM has a positive effect on service innovation. In addition, IM directly influences on competitive advantage. However, service innovation has no the effect of competitive advantage.

To gain competitive advantage in an organization comes from how to manage and construct communication, education \& training, reward, empowerment etc. Therefore, through IM 
activities such as having good communication system with members in hospital organization, specially between leader and members, shifting empowerment to members, providing proper and fair reward system, organization attempted to be transformed with accepting service innovation. This kind of internal marketing policy increases the employee satisfaction and loyalty. It in turn increase organization performance and decrease turnover rate. IM is managing a company's human resources based on a marketing perspective (Frye et al., 2019; Kotler et al., 2017). As seen in their view, an organization treats their employees as internal customers as the role of organization coaching. That's why, this paper showed that IM is a vital factor to organization's competitiveness as a view of organization coaching.

Consequently, we suggested that IM as organization coaching has a positive effect on service innovation and then is the core factor to enhance the competitive advantage. Therefore, this paper suggests practical implications for public hospital managers, including private hospital managers, from a management perspective.

For further research, it is meaningful that we study on regarding IM as a view of organization coaching more.

\section{References}

[1] A. Distanont and O. Khongmalai, "The role of innovation in creating a competitive advantage," Kasetsart Journal of Social Sciences, (2018) DIO: 10.1016/j.kjss.2018.07.009

[2] S. Chen, Y. Duan, J. S. Edwards, and B. Lehaney, "Toward understanding inter-organizational knowledge transfer needs in SMEs: insight from a UK investigation,” Journal of knowledge management, vol.10, no.3, pp.6-23, (2006) DOI: 10.1108/13673270610670821

[3] C. Wei Chong, S. Choy Chong, and G. Chew Gan, "Inter-organizational knowledge transfer needs among small and medium enterprises," Library Review, vol.60, no.1, pp.37-52, (2011) DOI: 10.1108/00242531111100568

[4] K. K. Papadas, G. J. Avlonitis, M. Carrigan, and L. Piha, "The interplay of strategic and internal Green marketing orientation on competitive advantage," Journal of Business Research, vol.104, pp.632-643, (2018) DOI: 10.1016/j.jbusres.2018.07.009

[5] C. Y. Ieong and D. Lam. "Role of internal marketing on employees' perceived job performance in an Asian integrated resort," Journal of Hospitality Marketing \& Management, vol.25, no.5, pp.589-612, (2016) DOI: 10.1080/19368623.2015.1067664

[6] Tsai, Y. F. and S. W. Wu, "New concept of nurse education for service innovation-A perspective of internal marketing," presented at the 6th IESM Conference, October, Seville, Spain, (2015) DOI: 10.1109/IESM.2015.7380174

[7] W. S. Bang, "Creating competitive advantage through internal marketing in the medical industry," Ph.D. dissertation, Gyeongsang Nationl University, (2017)

[8] K. R., Murphy and C. O. Davidshofer, "Psychological testing: Principles and applications," Engle-wood Cliffs, NJ: Prentice-Hall, (1988)

[9] I. C., Nunnally and I. H. Bernstin, "Psychometric theory (3rd ed.)," NY: McGraw-Hill, (1994)

[10] Frye W. D., Kang S., Huh C., and Lee, M. J. M. "What factors influence Generation Y's employee retention in the hospitality industry? An internal marketing approach," International Journal of Hospitality Management, 102352, (2019) DOI: 10.1016/j.ijhm.2019.102352

[11] P. Kotler, J.T. Bowen, J.C. Makens, and S. Baloglu, "Marketing for hospitality and tourism, 7th ed. Prentice Hall," Upper Saddle River, NJ, (2017) 


\section{Authors}

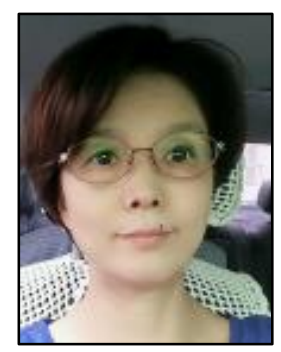

\section{Mi-sook Yeum}

Chief of Lifelong Center at Korea Human Resources Bank, Doctor of Christian Counseling-Coaching Ph.D Course at Canada Christian College. Her current research interests include safety management and leadership. Published papers in well-known Korean journals such as Koran Academy of Social.

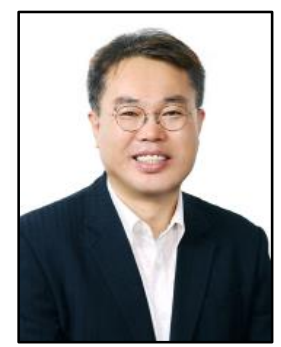

\section{Kuk-hoan Wee - Corresponding Author.}

Professor of Department of Convergence Wellness at Sungduk University, South Korea. Ph. D in Department of Law School from Donga University, South Korea. Ph. D. Courses in Marin Convergence Design, Pukyong National University, South Korea. Doctor of Christian CounselingCoaching Ph.D completion. His current research interests include safety management and leadership. Published papers in well-known Korean journals such as Koran Academy of Social Welfare.

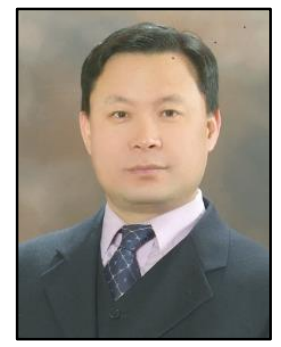

\section{Won-seok Bang - Corresponding author}

Lector of Department of Distribution at Gyeongnam National University of Science and Technology, South Korea. Ph. D in Department of business administrative from Gyeongsang National University, South Korea. His current research interests include marketing and leadership. Published papers in well-known Korean journals such as Korean Marketing Management Association. 